\title{
Autocrine Angiotensin System Regulation of Bovine Aortic Endothelial Cell Migration and Plasminogen Activator Involves Modulation of Proto-oncogene pp60 6 -src Expression
}

\author{
Leonard Bell, ${ }^{\star}$ Daniel J. Luthringer, ${ }^{\ddagger}$ Joseph A. Madri, ${ }^{\star}$ and Stephen L. Warren ${ }^{\star}$ \\ Section of Cardiovascular Medicine, Department of Internal Medicine, ${ }^{*}$ and Department of Pathology, \\ Yale University School of Medicine, New Haven, Connecticut 06510
}

\begin{abstract}
Rapid endothelial cell migration and inhibition of thrombosis are critical for the resolution of denudation injuries to the vessel wall. Inhibition of the endothelial cell autocrine angiotensin system, with either the angiotensin-converting enzyme inhibitor lisinopril or the angiotensin II receptor antagonist sar', ile $^{8}$-angiotensin II, leads to increased endothelial cell migration and urokinase-like plasminogen activator (u-PA) activity (Bell, L., and J. A. Madri. 1990. Am. J. Pathol. 137:7-12). Inhibition of the autocrine angiotensin system with the converting-enzyme inhibitor or the receptor antagonist also leads to increased expression of the proto-oncogene c-src: pp60-src mRNA increased 7-11-fold, c-src protein 3-fold, and c-src kinase activity 2-3fold. Endothelial cell expression of c-src was constitutively elevated after stable infection with a retroviral vector containing the c-src coding sequence. Constitutively increased c-src kinase activity reconstituted the increases in migration and u-PA observed with angiotensin system interruption. Antisera to bovine u-PA blocked the increase in migration associated with increased c-src expression. These data suggest that increases in endothelial cell migration and plasminogen activator after angiotensin system inhibition are at least partially pp60-src mediated. Elevated c-src expression with angiotensin system inhibition may act to enhance intimal wound closure and to reduce luminal thrombogenicity in vivo. (J. Clin. Invest. 1992. 89:315-320.) Key words: angiotensin-converting enzyme inhibitor $\cdot$ blood vessel $\bullet$ gene transfer $\cdot$ proto-oncogene $\cdot$ tyrosine kinase
\end{abstract}

\section{Introduction}

Rapid migration of endothelial cells to reconstitute a continuous endothelial cell monolayer following blood vessel injury is an important mechanism for the restoration of vessel wall integrity (1-5). Further, thrombus formation at the sites of vessel

Address reprint requests to Dr. Bell, Section of Cardiovascular Medicine, Department of Internal Medicine, Yale University School of Medicine, 333 Cedar Street, New Haven, CT 06510.

Received for publication 7 June 1991 and in revised form 11 September 1991.

J. Clin. Invest.

(c) The American Society for Clinical Investigation, Inc.

0021-9738/92/01/0315/06 \$2.00

Volume 89, January 1992, 315-320 injury contributes to vessel injury and lumen occlusion $(6,7)$. Studies in animal models of hypertension, hyperlipidemia, and angioplasty have suggested that the angiotensin system may modulate the response of the vessel wall to injury since interruption of the renin-angiotensin system results in improved vessel patency $(8-10)$. In vitro, investigators have demonstrated that many of the constituents of the renin-angiotensin system, including angiotensinogen, renin, angiotensin-converting enzyme, and angiotensin II receptors, are contained within endothelial cells (11-15). Further, interruption of an endothelial cell autocrine angiotensin system is associated with increases in endothelial cell migration and urokinase-like plasminogen activator (u-PA) ${ }^{1}$ activity (16). Strategies, such as interruption of the angiotensin system, which stimulate endothelial cell migration and $\mathrm{u}-\mathrm{PA}$ expression may favorably impact upon the vessel wall response to injury.

Other investigators have demonstrated that elevated expression of pp60 $60^{\mathrm{v}-\mathrm{src}}$, the viral homologue of the proto-oncogene pp $60^{\text {c-src }}$, induces $\mathrm{u}-\mathrm{PA}$ expression (17). This observation raises the possibility that the cellular homologue, c-src, may also elevate u-PA expression. Hence, the present study was designed to determine: $(a)$ whether an increase in c-src expression coincides with the changes in migration and u-PA expression induced by interruption of the autocrine angiotensin system; $(b)$ whether elevated expression of pp $60^{\text {c-src }}$ leads to increased endothelial cell migration and u-PA expression; and (c) whether the increase in cell migration associated with elevated expression of pp60 $60^{\text {c-src }}$ is dependent upon increased u-PA activity.

\section{Methods}

Cell culture, migration, proliferation, and cell size. Bovine aortic endothelial cells (BAEC) were isolated, cultured with DME (Gibco Laboratories, Grand Island, NY) and 10\% fetal calf serum (Gibco Laboratories), and characterized as previously described (18). Endothelial cells were first seeded into the middle of a steel fence and allowed to attach to the underlying type I collagen matrix below; after cell attachment, the fence was removed and, with the loss of contact inhibition, the monolayer of cells commenced radial migration outward over a 6-d period (18). Lisinopril (Merck, Sharp \& Dohme, West Point, PA) was administered at a final concentration of $1 \mu \mathrm{M}$ and the angiotensin II receptor antagonist sar $^{1}$, ile $^{8}$-angiotensin II (Sigma Chemical Co., St. Louis, MO) was administered daily at a final concentration of $1 \mu \mathrm{M}$, since

1. Abbreviations used in this paper: BAEC, bovine aortic endothelial cell(s); RIPA, radioimmunoprecipitation assay; u-PA, urokinase-like plasminogen activator. 
previous studies have demonstrated that these doses effectively inhibit the endothelial cell autocrine angiotensin system in vitro (16). In addition, the dose of lisinopril employed in the present study is similar to the dose of angiotensin inhibitors employed in recent in vivo studies (10). It is unlikely that the effects observed with the angiotensin-converting enzyme inhibitor and the angiotensin II receptor antagonist are related to angiotensin system components in the media since neither angiotensinogen, angiotensin I, nor angiotensin II are detectable in calf serum or DME (11) and renin activity is less than $0.1 \mathrm{ng} / \mathrm{ml} \mathrm{per} \mathrm{h}$ in our media with serum as determined by radioimmunoassay (data not shown). The role of u-PA in mediating the changes in cell migration was evaluated during 3-d migrations of endothelial cells treated with either 5\% immune anti-bovine urokinase antiserum (19; generously provided by $\mathrm{D}$. Rifkin) administered daily, or $5 \%$ nonimmune rabbit serum administered daily. The possible contribution of changes in cell proliferation during migration to changes in cell migration was assessed by determining the number of cells present in a sample obtained from trypsinization of migrating cells under different conditions with a counter (Coulter Electronics, Inc., Hialeah, FL). Cell sizes during migration were measured on approximately 100 cells per treatment by morphometric analysis with a digitizing tablet (16).

Immunoblot analysis. Cell protein was extracted with RIPA buffer ( $1 \%$ Triton $\mathrm{X}-100,1 \%$ sodium deoxycholate, $0.1 \% \mathrm{SDS}, 0.15 \mathrm{M} \mathrm{NaCl}$, $0.05 \mathrm{M}$ Tris-HCl, pH 7.2, $1 \mathrm{mM}$ PMSF, and $0.2 \mathrm{mM}$ vanadate) and normalized for total protein using the bicinchonic acid assay (20). Equal protein loads of the cell lysates were run on a $6 \%$ reducing polyacrylamide gel, transferred to nitrocellulose paper, blocked with $4 \%$ PBSA, and incubated with anti-src monoclonal antibody (MAb327) (Oncogene Science, Inc., Manhasset, NY) $(21,22)$. This antibody also immunoblots and precipitates c-src in cells derived from a wide variety of species including bovine vascular smooth muscle cells (23), chicken (24), rat (Marx, M., J. A. Madri, L. Bell, unpublished observations), and canine (25) cells. Normal mouse sera does not immunoblot or precipitate the appropriate $60-\mathrm{kD}$ moiety from bovine, canine, and rat cells (data not shown). The immunoblots were developed with rabbit anti-mouse IgG and ${ }^{125} \mathrm{I}$-protein $\mathrm{A}$ and then exposed to XAR film (Eastman Kodak Co., Rochester, NY) at $-70^{\circ} \mathrm{C}$. Quantitative determinations of relative amounts of the src protein were performed using a densitometer (Hoefer Scientific Instruments, San Francisco, CA).

Kinase assay. Cell protein was extracted with RIPA buffer and normalized for total protein as above. Equal amounts of cell protein were then precleared with normal mouse IgG and incubated overnight with MAb327. The antigen/antibody complexes were precipitated with protein A Sepharose beads, washed with RIPA buffer, and subsequently suspended in $20 \mathrm{mM}$ Tris- $\mathrm{HCl}, \mathrm{pH} 7.2,5 \mathrm{mM} \mathrm{MgCl}_{2}$ with $10 \mu \mathrm{Ci}$ $\gamma^{32} \mathrm{ATP} /$ reaction for $10 \mathrm{~min}$ at $30^{\circ} \mathrm{C}(25)$. The reaction was stopped with excess unlabeled ATP. The beads were boiled in solubilization buffer, loaded on a $10 \%$ reducing polyacrylamide gel, and the gel was developed with XAR film at $-70^{\circ} \mathrm{C}$. Quantitative determinations of relative amounts of the src kinase activity were performed using a densitometer (Hoefer Scientific Instruments).

Plasminogen activator activity assay. u-PA activity was measured using the chromogenic substrate H-D-norleucyl-hexahydrotyrosyl-lysine-p-nitroanilide diacetate salt (American Diagnostica, Inc., Greenwich, CT) at a final concentration of $250 \mathrm{mM}$ and human plasminogen at a final concentration of $25 \mu \mathrm{g} / \mathrm{ml}$ in $120 \mathrm{mM}$ Tris- $\mathrm{HCl}, \mathrm{pH} 8.7$ as previously described (16). These results were confirmed by plasminogen zymography, modified from Granielli-Piperino and Reich (26) with final concentrations of nonfat milk $4 \%, 0.1 \mathrm{M}$ Tris- $\mathrm{HCl} \mathrm{pH} 7.2,8$ $\mu \mathrm{g} / \mathrm{ml}$ plasminogen, and $1.25 \%$ agar.

Northern blot analysis. Total cellular RNA was extracted with $4 \mathrm{M}$ guanidinium $\mathrm{HCl}, 5 \mathrm{mM}$ sodium citrate $\mathrm{pH} 7.0,0.1 \% \beta$-mercaptoethanol, and $0.5 \%$ Sarkosyl, centrifuged on a cushion of $5.7 \mathrm{M} \mathrm{CsCl}$ in 0.1 $M$ EDTA, and reextracted with a 4:1 mixture of chloroform and 1-butanol and ethanol precipitation (27). Total cellular RNA, $20 \mu \mathrm{g}$ per lane, was electrophoresed through a $1 \%$ formaldehyde gel, transferred to Nytran filters, and prehybridized with $0.5 \mathrm{M}$ sodium phosphate, $\mathrm{pH}$ $7.2,7 \%$ SDS, $1 \%$ BSA, 1 mM EDTA for $2 \mathrm{~h}$ at $65^{\circ} \mathrm{C} \mathrm{(28).} \mathrm{The} \mathrm{blot} \mathrm{was}$ hybridized overnight at $65^{\circ} \mathrm{C}$ with the labeled dCT ${ }^{32} \mathrm{P} \mathrm{c}$-src DNA probe (25), washed twice with $2 \times \mathrm{SSC}$ and $0.1 \% \mathrm{SDS}$ for $30 \mathrm{~min}$ at $65^{\circ} \mathrm{C}$, and developed against XAR film at $-70^{\circ} \mathrm{C}$. Quantitative determinations of relative amounts of the src mRNA were performed using a densitometer (Hoefer Scientific Instruments). All immunoblots, kinase assays, and RNA hybridizations were performed at least two times.

Transfections and infections. The c-src coding sequence was spliced into the helper-free Moloney retroviral vector Mcsrc $\Delta$ iSVneo[+] (25). Mcsrc $\Delta \mathrm{i} 295 \mathrm{SVneo}(+)$, a similar virus which encodes a kinase-negative mutant of c-src, Met-295 (29), and a control virus, Hippo42, that encodes $\mathrm{Tn} 5$ aminoglycoside phosphotransferase ( $\left.\mathrm{NeO}^{\top}\right)$ were also employed. $\psi$-2 cells were transfected with plasmid DNA using polybrene/ DMSO shock. $\psi$-2 cells were selected in G418 (Sigma Chemical Co.), and the filtered media from resistant cells was used to infect $\psi$-AM cells (30). The resulting amphotropic virus was then used to infect subconfluent BAEC which were selected in $\mathrm{G} 418,400 \mu \mathrm{g} / \mathrm{ml}$, until all uninfected BAEC were killed ( $10 \mathrm{~d})$.

Immunofluorescence. Migrating cells were washed four times with PBS, fixed with periodate-lysine-paraformaldehyde fixative, permeabilized with $0.2 \%$ Triton $X-100$, and blocked overnight with PBS with $3 \%$ BSA. Cells were incubated with either nonimmune rabbit serum or rabbit anti-bovine u-PA antisera (generously supplied by D. Rifkin) and rhodamine-conjugated goat anti-rabbit secondary antibody. Cells were examined on an MRC-600 confocal microscope (Bio-Rad Laboratories, Richmond, CA). Cells incubated with nonimmune serum demonstrated no detectable staining.

Statistical analysis. Changes in migration, proliferation, cell size, and u-PA activity were analyzed by analysis of variance and correction was made for multiple comparisons using the method of Bonferroni. Statistical significance was assumed for $P<0.05$.

\section{Results}

Inhibition of the endothelial cell autocrine angiotensin system with either the angiotensin-converting enzyme inhibitor, lisinopril, or the angiotensin II receptor antagonist sar ${ }^{1}$, ile $^{8}$-angiotensin II leads to increased pp60-src expression (Fig. 1). Lisinopril and $\operatorname{sar}^{1}$, ile ${ }^{8}$-angiotensin II increased endothelial cell steady-state c-src mRNA 11- and 7-fold, c-src protein 3-fold, and c-src kinase activity 3-and 2-fold, respectively. The endogenous c-src steady-state protein level in untreated migrating endothelial cells did not differ from the steady-state level in untreated confluent cells as determined by immunoblotting (data not shown). The presently observed $3.6-\mathrm{kb}$ c-src transcript differs from the 3.9-4.0-kb transcript found most frequently in vertebrate tissues $(24,25,31)$. The structure of this possibly novel transcript is presently under investigation.

The increase in c-src expression may be an epiphenomenon that is associated with inhibition of the autocrine angiotensin system; alternatively, increased $\mathrm{pp} 60^{\mathrm{c}-\mathrm{src}}$ expression may lead to more rapid endothelial cell migration and increased plasminogen activator activity. To test this latter possibility, the c-src gene was transferred into subconfluent BAEC using the amphotropic, helper-free retrovirus Mcsrc $\Delta \mathrm{iSV}$ neo(+). In addition, endothelial cells were also infected with the kinase negative c-src mutant, Mcsrc $\Delta \mathrm{i} 295 \mathrm{SV}$ neo(+), and a control virus, Hippo42, that encodes Tn5 aminoglycoside phosphotransferase $\left(\mathrm{Neo}^{\mathrm{r}}\right)$ (Fig. 2). The steady-state level of the c-src retroviral mRNA transcript was fourfold greater in endothelial cells that expressed the kinase-negative mutant than in cells that expressed elevated levels of wild-type c-src. In addition, c-src was expressed from the provirus at levels higher than endogenous c-src since hybridization to the message derived from the provirus was apparent at $<1 \mathrm{~d}$ while hybridization to the endoge- 


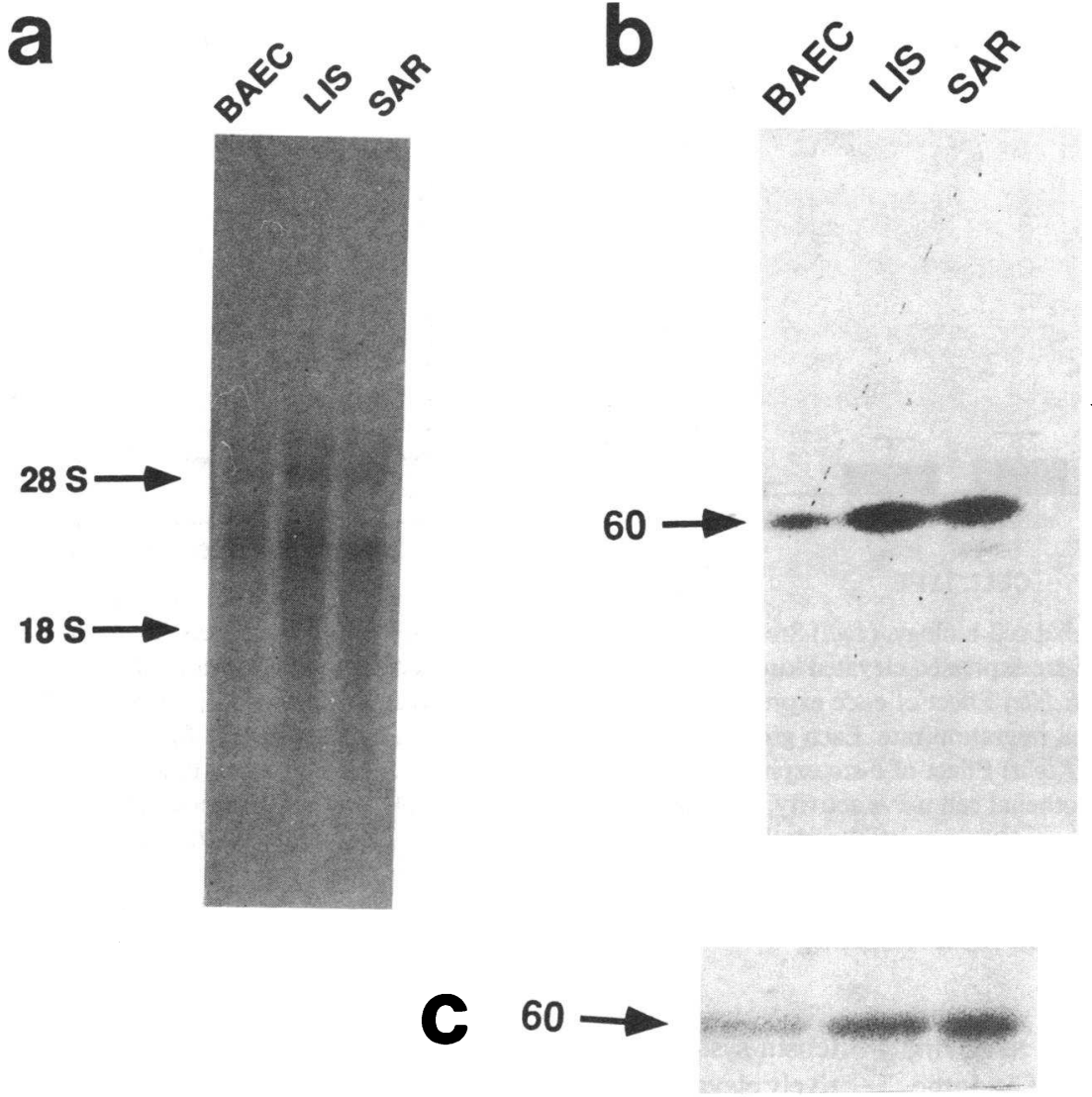

Figure 1. Expression of endogenous c-src in endothelial cells. Control endothelial cells, cells treated with lisinopril $(L I S)(1 \mu \mathrm{M})$, and cells treated with $\operatorname{sar}^{1}$, ile ${ }^{8}$-angiotensin II $(S A R)(1 \mu \mathrm{M})$. (a) Hybridization of radiolabeled c-src DNA probe to endothelial cell RNA. The 3.6-kb c-src transcript is denoted by the arrowhead. Inhibition of endothelial cell autocrine angiotensin II stimulation was associated with an increase in steady state c-src mRNA levels. The autoradiogram is overexposed intentionally to reveal the low levels of endogenous c-src mRNA. (b) Src kinase activity determined by the in vitro kinase assay. Inhibition of endothelial cell autocrine angiotensin II stimulation was associated with increased c-src autophosphorylation. (c) Immunoblot showing expression of pp60 $60^{\text {serc }}$ protein levels. The autoradiogram was developed at $-70^{\circ} \mathrm{C}$ for $7 \mathrm{~d}$. Inhibition of endothelial cell autocrine angiotensin II stimulation was associated with an increase in steady-state pp60 $60^{\text {serc }}$ protein levels. nous message was apparent after a 7-d exposure (Fig. 1). The in vitro src kinase activity was two- to threefold greater in the cells that expressed elevated levels of c-src than in cells that expressed the kinase-negative mutant or $\mathrm{Neo}^{\mathrm{r}}$ alone (Fig. 3, left); however, the steady-state src protein levels, determined by immunoblotting, were 11-fold greater in endothelial cells that expressed the kinase negative mutant than in cells that expressed elevated levels of c-src.

Endothelial cells that expressed elevated levels of c-src migrated at a markedly faster rate in the fence assay than cells that expressed the kinase-negative mutant, $\mathrm{Neo}^{\mathrm{r}}$ alone, or noninfected cells (Fig. 3, middle). Infected endothelial cells did not overgrow monolayers or proliferate in suspension, were contact inhibited, exhibited sheet migration, and retained factor VIII staining. The cells that expressed elevated levels of c-src appeared rounder and less flattened than the cells that expressed $\mathrm{NeO}^{\mathrm{r}}$ alone, but their cytoplasmic areas were similar (552 \pm 19 vs. $626 \pm 63 \mu \mathrm{m}^{2}$, respectively, $P=\mathrm{NS}$ ). The prolifera- tion rates (determined by cell counting) of migrating cells that expressed elevated c-src levels, elevated levels of the kinasenegative mutant, and neo ${ }^{\mathrm{r}}$ alone did not differ significantly from each other (data not shown). In addition, u-PA activity was significantly greater in endothelial cells that expressed elevated levels of c-src than in cells that expressed the kinase-negative mutant, Neo ${ }^{\mathrm{r}}$ alone, or noninfected endothelial cells (Fig. 3 , right). Although the kinase-negative mutant src protein was expressed at levels greater than the c-src protein, no biologic effects were observed with expression of the kinase-negative mutant src protein. The increased level of u-PA in migrating endothelial cells, induced by lisinopril or expressed from the Mcsrc $\Delta$ iSVneo(+) provirus, was also revealed by immunofluorescence studies (Fig. 4).

The increase in migration associated with elevated expression of $\mathrm{c}$-src is dependent in part on the associated increase in u-PA activity since administration of antisera to bovine u-PA inhibited the increase in migration associated with enhanced

HIppo 42

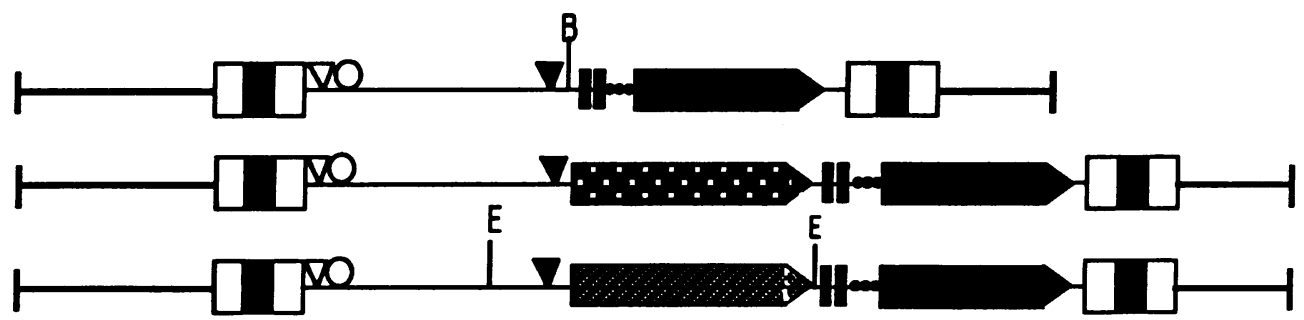

Mcsrc $\Delta 15 V n e o[+]$

Figure 2. Retroviral vectors used to infect bovine aortic endothelial cells. Abreviations: $\square=L T R ; \nabla=5^{\prime}$ splice site; $O=\psi$ packaging signal; $\nabla=3^{\prime}$

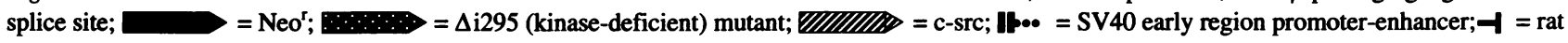
genomic DNA; E = EcoRI; $\mathbf{B}=$ BamH1. 

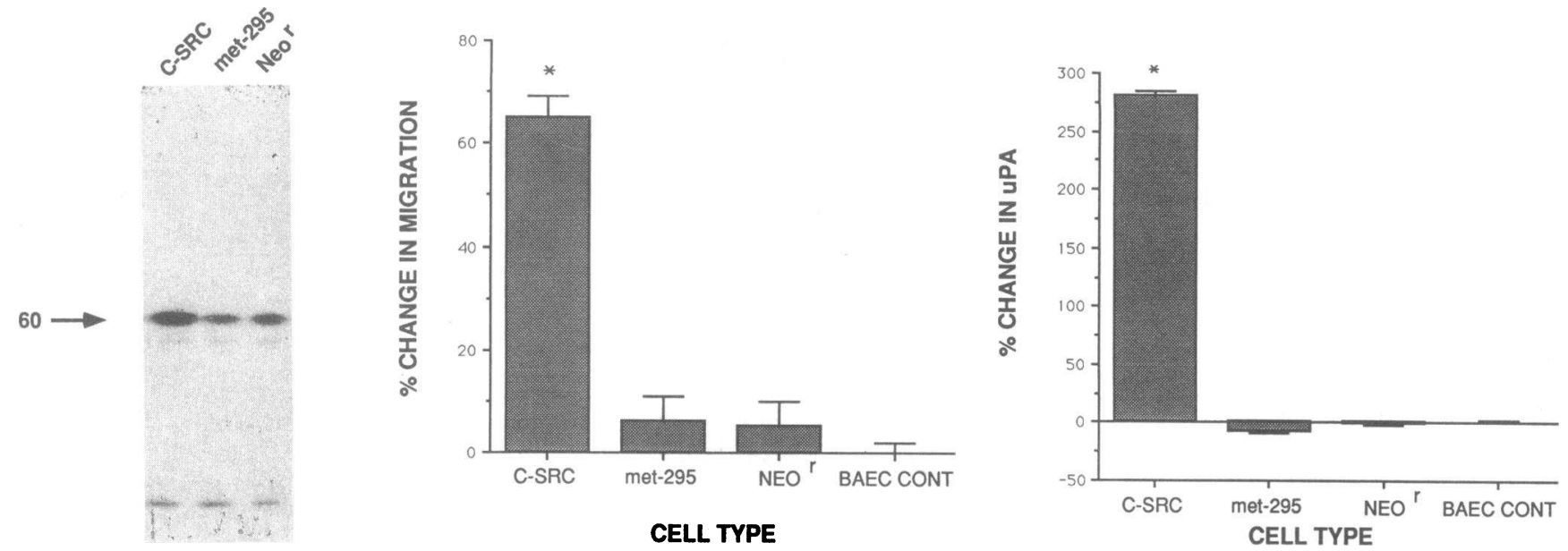

Figure 3. Effect of elevated c-src expression on endothelial cell biology. (Left) Src kinase activity determined by the in vitro kinase assay. Endothelial cells derived by infection with viruses encoding c-src expressed elevated kinase activity compared to cells derived by infection with viruses encoding the kinase negative mutant or $\mathrm{Neo}^{\mathrm{r}}$ alone. (Middle) Effect of c-src expression on endothelial cell migration. Elevated pp60-arc kinase expression was associated with increased endothelial cell migration rate. Each group contained 8-10 replicates and the mean \pm 1 SEM are expressed. ${ }^{*} P<0.001$ vs. noninfected endothelial cells. (Right) Effect of $c$-src expression on endothelial cell u-PA activity during migration. Elevated pp $60^{\text {c-src }}$ kinase expression leads to increased endothelial cell u-PA activity. Each group contained five replicates and the mean \pm 1 SEM are expressed. u-PA activity was $4.9 \pm 0.05 \mathrm{mPU} / \mu \mathrm{g}$ cell protein in control endothelial cells. Similar results were obtained with standard plasminogen zymography (data not shown). ${ }^{*} P<0.001$ vs. noninfected endothelial cells. Abbreviations: $C$-SRC, endothelial cells expressing elevated levels of c-src; met-295, endothelial cells expressing the kinase negative mutant c-src, met-295; $N E O^{r}$, endothelial cells expressing Tn5 aminoglycoside phosphotransferase alone; $B A E C C O N T$, noninfected endothelial cells.

c-src expression (Fig. 5). Administration of antisera to bovine u-PA did not significantly influence the migration of endothelial cells that expressed $\mathrm{NeO}^{\mathrm{r}}$ alone.

\section{Discussion}

This study demonstrates that inhibition of the endothelial cell autocrine angiotensin system leads to the previously observed increases in cell migration and u-PA, at least in part, via elevated expression of the proto-oncogene c-src. The role of c-src in mediating these changes in endothelial cell behavior is suggested by the dual observations that interruption of the angio- tensin system leads to elevated c-src expression and constitutively elevated expression of c-src leads to increased endothelial cell migration and u-PA. The increase in migration associated with elevated c-src expression is dependent upon the associated increase in u-PA activity.

Regulation of endothelial cell migration involves modulation of varied cell functions including cell membrane-associated proteases, extracellular matrix, matrix receptors, cytoskeletal organization, cell spreading and shape, gap junction formation, and cell-cell communication (32-34). C-src and its viral counterpart, v-src, affect cellular systems that may influence cell migration. Elevated expression of the membrane-as-
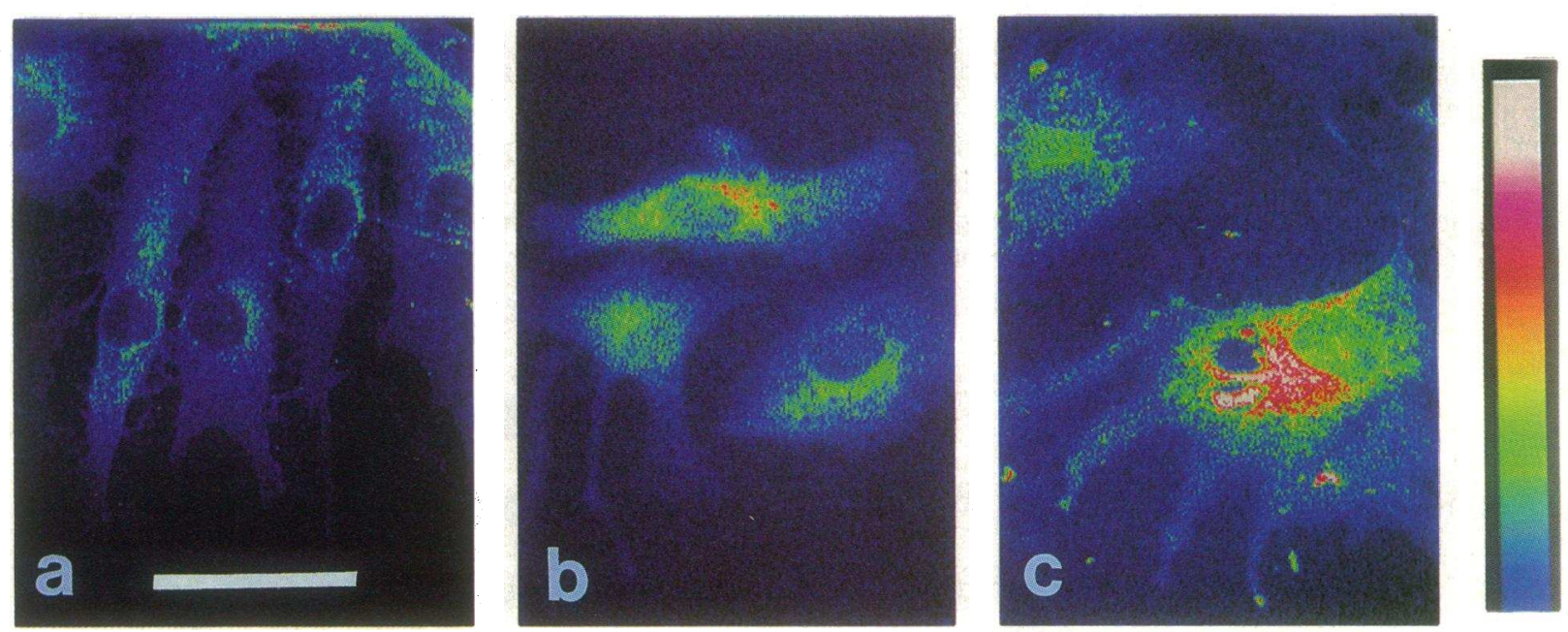

Figure 4. Expression of u-PA in endothelial cells at the leading edge of migration. (a) cells expressing neor alone, (b) cells expressing elevated levels of c-src, and $(c)$ lisinopril-treated cells. Cells that expressed elevated levels of c-src, either due to lisinopril treatment or expression of the provirus, demonstrated substantial increases in immunoreactive u-PA antigen as compared to cells expressing neo alone. Bar, $50 \mu \mathrm{m}$. 


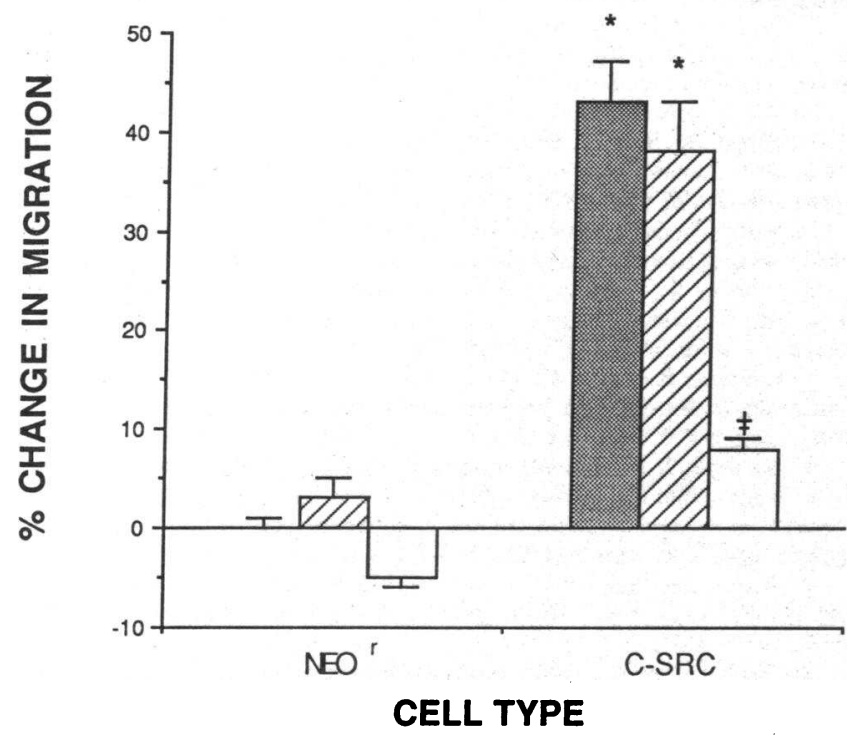

Figure 5. Effect of antisera to bovine u-PA on c-src induced endothelial cell migration. Untreated endothelial cells that expressed c-src migrated at a faster rate than cells that expressed $\mathrm{Neo}^{\mathrm{r}}$ alone (dark bars). Nonimmune rabbit antisera (cross-hatched bars) did not affect endothelial cell migration compared to untreated cells for either cell type. Administration of antisera to bovine u-PA (open bars) did not affect $\mathrm{Neo}^{r}$ migration but significantly inhibited c-src migration. Each group contained four replicates and the mean \pm 1 SEM are expressed. ${ }^{*} P<0.001$ vs. $\mathrm{Neo}^{\mathrm{r}}$ cells; $\ddagger P<.01$ vs. $\mathrm{c}$-src cells without treatment. Abbreviations: $N E O^{r}$, endothelial cells expressing Tn5 aminoglycoside phosphotransferase alone; C-SRC, endothelial cells expressing elevated levels of c-src.

sociated tyrosine kinase c-src induces marked cytoskeletal reorganization in epithelial cells and reduces cell-to-cell macromolecule transmission in fibroblasts $(25,35)$. In addition, v-src, which tyrosine phosphorylates a wider range of proteins in cells than does c-src (36), enhances plasminogen activator gene expression, reduces surface-associated fibronectin, phosphorylates fibronectin-binding integrins, and reduces cell spreading on a fibronectin matrix $(17,37-39)$.

While the presently observed enhanced endothelial cell uPA activity associated with elevated c-src expression would be expected to contribute to thrombus lysis at sites of injury in vivo, the cell-associated plasminogen activator system has also been suggested by investigators to play a central role in regulating vascular cell migration via either activation/inhibition of direct cleavage of cell-matrix attachments or via activation/inhibition of other protease systems which then cleave cell-matrix attachments (40). Indeed, investigators have demonstrated that constitutively elevated expression of urokinase is associated with an increase in the invasive motility of mouse $\mathrm{L}$ cells and murine melanoma B16-F1 cells $(41,42)$. In the present study, administration of antisera to bovine u-PA inhibits the increase in migration associated with elevated c-src expression (Fig. 5), suggesting that the increase in migration is in part dependent upon the associated increased u-PA activity. The effect of the u-PA antisera to inhibit the migration of c-src expressing cells, but not the migration of cells that express $\mathrm{Neo}^{\mathrm{r}}$ alone, may be related to a greater contribution of the increased level of u-PA to cell migration in c-src expressing cells than in control cells. This may be due to an increase in the direct effect of u-PA on sheet migration in the c-src expressing cells. Alternatively, the observed results may be due to an enhanced indirect action of the increased u-PA level to activate other proteases which then contribute to the increased sheet migration in the c-src expressing cells. This latter possibility is supported by our observation of the induction of an $\sim 100 \mathrm{kD}$ metalloprotease in c-src expressing cells but not in control cells (Bell, L., and J. A. Madri, unpublished observations).

Although this study demonstrates that increased expression of c-src kinase activity is sufficient to reconstitute the increases in endothelial cell plasminogen activator activity and migration associated with interruption of the angiotensin system, we have not yet identified other molecules that might be involved in producing these biologic effects. We are currently examining phosphoproteins in endothelial cells which might be potential substrates of the c-src tyrosine kinase. Further, the angiotensin system can regulate c-myc and c-jun mRNA expression in nonendothelial cells (42-48) and c-src can alter the regulation of c-fos transcription which can also regulate these proto-oncogenes (49-51). Thus, changes in the expression of these nuclear proto-oncogenes after angiotensin system interruption may also contribute to the observed changes in endothelial cell behavior.

Finally, it is possible that the reduced vessel wall injury associated with interruption of the angiotensin system in animal models of hypertension, hyperlipidemia, and angioplasty (8-10) may involve elevated levels of endothelial cell c-src in vivo. Therapies directed at elevating the level of endothelial cell c-src activity in vivo, either directly through genetic modification or indirectly via pharmacologic manipulations, may have a beneficial effect on the vessel wall response to injury by enhancing endothelial cell migration to close the intimal wound and by reducing luminal thrombogenicity via enhanced surface plasminogen activator activity.

\section{Acknowledgments}

We thank Merck, Sharp \& Dohme for the generous supply of lisinopril, D. L. Rifkin for the generous gift of antisera to bovine u-PA, A. Tucker for technical assistance, and Dr. M. Marx for critical reading of the manuscript.

This work was supported by Physician Scientist Award 5K11 HL02351 to Dr. Bell and R01 HL-28373 to Dr. Madri.

\section{References}

1. Ross, R. 1986. The pathogenesis of atherosclerosis-an update. N. Engl. J. Med. 314:488-500.

2. Reidy, M. A., and S. M. Schwartz. 1981. Endothelial regeneration. III. Time course of intimal changes after small defined injury to rat aortic endothelium. Lab. Invest. 44:301-308.

3. Schwartz, S. M., C. C. Haudenschild, and E. M. Eddy. 1978. Endothelial regeneration. I. Quantitative analysis of initial stages of endothelial regeneration in rat aortic intima. Lab. Invest. 38:568-580.

4. Sholley, M. M., M. A. Gimbrone, Jr., and R. S. Cotran. 1977. Cellular migration and replication in endothelial regeneration: a study using irradiated endothelial cultures. Lab. Invest. 36:18-25.

5. Madri, J. A., and K. S. Stenn. 1982. Aortic endothelial cell migration. I. Matrix requirements and composition. Am. J. Pathol. 106:180-186.

6. Kennedy, J. W., J. L. Ritchie, K. B. Davis, M. L. Stadius, C. Maynard, and J. K. Fritz. 1985. The Western Washington randomized trial of intracoronary streptokinase in acute myocardial infarction. N. Engl. J. Med. 312:1073-1078.

7. Miller, K. P., and W. H. Frishman. 1988. Platelets and antiplatelet therapy in ischemic heart disease. Med. Clin. N. Am. 72:117-184.

8. Chobanian, A. V., C. C. Haudenschild, C. Nickerson, and R. Drago. 1990. Antiatherogenic effect of captopril in the Watanabe heritable hyperlipidemic rabbit. Hypertension. 15:327-331. 
9. Owens, G. K. 1987. Influence of blood pressure on development of aortic medial smooth muscle hypertrophy in spontaneously hypertensive rats. Hypertension. 9:178-187.

10. Powell, J. S., J.-P. Clozel, R. K. M. Muller, H. Kuhn, F. Hefti, M. Hosang and H. R. Baumgartner. 1989. Inhibitors of angiotensin-converting enzyme prevent myointimal proliferation after vascular injury. Science (Wash. DC). 245:186-188.

11. Lilly, L. S., R. E. Pratt, R. W. Alexander, D. M. Larson, K. E. Ellison, M. A. Gimbrone, and V. J. Dzau. 1985. Renin expression by vascular endothelia cells in culture. Circ. Res. 57:312-318.

12. Caldwell, P. R. B., B. C. Seegal, and K. C. Hsu. 1976. Angiotensin-converting enzyme: vascular endothelial localization. Science (Wash. DC). 191:1050-1051.

13. Ryan, U. S., J. W. Ryan, C. Whitaker, and A. Chiu. 1976. Localization of angiotensin converting enzyme (kininase II). II. Immunocytochemistry and immunofluorescense. Tissue Cell. 8:125-145.

14. Johnson, A. R., and E. G. Erdos. 1977. Metabolism of vasoactive peptides by human endothelial cells in culture: angiotensin I converting enzyme (kininase

II) and angiotensinase. J. Clin. Invest. 59:684-695

15. Patel, J. M., F. R. Yarid, E. R. Block, and M. K. Raizda. 1989. Angiotensin receptors in pulmonary arterial and aortic endothelial cells. Am. J. Physiol. 256:C987-C993.

16. Bell, L., and J. A. Madri. 1990. Influence of the angiotensin system on endothelial and smooth muscle cell migration. Am. J. Pathol. 137:7-12.

17. Bell, S. M., R. W. Brackenbury, N. D. Leslie, and J. L. Degen. 1990. Plasminogen activator gene expression is induced by the src oncogene product and tumor promoters. J. Biol. Chem. 265:1333-1338.

18. Bell, L., and J. A. Madri. 1989. Effect of platelet factors on migration of cultured bovine aortic endothelial and smooth muscle cells. Circ. Res. 65:10571065.

19. Saksela, O., and D. B. Rifkin. 1990. Release of basic fibroblast growth factor-heparan sulfate complexes from endothelial cells by plasminogen activator-mediated proteolytic activity. J. Cell Biol. 110:767-775.

20. Smith, P. K., R. I. Krohn, G. T. Hermansion, A. K. Mallia, F. H. Gartner, M. D. Provenzano, E. K. Fujimoto, N. M. Goeke, B. J. Olson, and D. C. Klenk 1985. Measurement of protein using bicinchonic acid. Anal. Biochem. 150:7685.

21. Knecht, D. A., and R. L. Dimond. 1984. Visualization of antigenic proteins on Western blots. Anal. Biochem. 136:180-184.

22. Blake, M. S., K. H. Johnston, G. J. Russell-Jones, and E. C. Gotschlich 1984. A rapid, sensitive method for detection of alkaline phosphatase-conjugated anti-antibody on Western blots. Anal. Biochem. 136:175-179.

23. DiSalvo, J., D. Gifford, and A. Kokkinakis. 1988. pp60-arc kinase activity in bovine coronary extracts is stimulated by ATP. Biochem. Biophys. Res. Com mun. 153:388-394.

24. Dorai, T., and L.-H. Wang. 1990. An alternative non-tyrosine protein kinase product of the c-src gene in chicken skeletal muscle. Mol. Cell. Biol. 10:4068-4079.

25. Warren, S. L., L. M. Handel, and W. J. Nelson. 1988. Elevated expression of pp60 6 -src alters a selective morphogenetic property of epithelial cells in vitro without a mitogenic effect. Mol. Cell. Biol. 8:632-646.

26. Granelli-Piperino, A., and E. Reich. 1978. A study of proteases and protease-inhibitor complexes in biological fluids. J. Exp. Med. 148:223-234.

27. Maniatis, T., E. F. Fritsch, and J. Sambrook. 1982. Molecular Cloning: a Laboratory Manual. Cold Spring Harbor Laboratory, Cold Spring Harbor, NY. 196.

28. Mahmoudi, M., and V. K. Lin. 1989. Comparison of two different hybridization systems in Northern transfer analysis. Biotechniques. 7:331-333.

29. Jove, R., S. Kornbluth, and H. Hanafusa. 1987. Enzymatically inactive p60c-src mutant with altered ATP-binding site is fully phosphorylated in its carboxy-terminal regulatory region. Cell. 50:937-43.

30. Cone, R. D., and R. C. Mulligan. 1984. High-efficiency gene transfer into mammalian cells: generation of helper-free recombinant retrovirus with broad mammalian host range. Proc. Natl. Acad. Sci. USA. 81:6349-6353.

31. Wang, L.-H., S. Iijima, T. Dorai, and B. Lin. 1987. Regulation of the expression of proto-oncogene c-src by alternative RNA splicing in chicken skeletal muscle. Oncogene Res. 1:43-59.
32. Madri, J. A., L. Bell, M. Marx, J. R. Merwin, C. T. Basson, and C. Prinz. 1990. The effects of soluble factors and extracellular matrix components on vascular cell behavior in vitro and in vivo: models of de-endothelialization and repair. J. Cell. Biochem. 45:123-130.

33. Pepper, M. S., D. C. Spray, M. Chanson, R. Montesano, L. Orci, and P. Meda. 1989. Junctional communication is induced in migrating capillary endothelial cells. J. Cell Biol. 109:3027-3038.

34. Selden, S., and S. Schwartz. 1979. Cytochalasin B inhibition of endothelial proliferation at wound edges in vitro. J. Cell Biol. 81:348-354.

35. Azarnia, R., S. Reddy, T. E. Kmiecik, D. Shalloway, and W. R. Lowenstein. 1988. The cellular src gene product regulates junctional cell-to-cell communication. Science (Wash. DC). 23:398-401.

36. Coussens, P. M., J. A. Cooper, T. Hunter, and D. Shalloway. 1985. Restriction of the In Vitro and In Vivo tyrosine protein kinase activities of pp60-arc relative to pp60v-ssc. Mol. Cell. Biol. 5:2753-2763.

37. Kellie, S., B. Patel, A. Mitchell, D. R. Critchley, N. M. Wigglesworth, and J. A. Wyke. 1986. Comparison of the relative importance of tyrosine-specific vinculin phosphorylation and the loss of surface-associated fibronectin in the morphology of cells transformed by Rous sarcoma virus. J. Cell. Sci. 82:129-142.

38. Rohrschneider, L., and S. Reynolds. 1985. Regulation of cellular morphology by the Rous sarcoma virus src gene: analysis of fusiform mutants. Mol. Cell. Biol. 5:3097-3107.

39. Tapley, P., A. Horwitz, C. Buck, K. Duggan, and L. Rohrschneider. 1989. Integrins isolated from Rous sarcoma virus-transformed cheiken embryo fibroblasts. Oncogene. 4:325-333.

40. Knudsen, B. S., and R. L. Nachman. 1988. Matrix plasminogen activator inhibitor. Modulation of the extracellular proteolytic environment. J. Biol. Chem. 263:9476-9481.

41. Cajot, J.-F., S. W.-D., R. L. Medcalf, J. Bamat, J. Testuz, L. Liebermann, and B. Sordat. 1989. Mouse L cells expressing human prourokinase-type plasminogen activator: effects on extracellular matrix degradation and invasion. $J$. Cell Biol. 109:915-925.

42. Yu, H., and R. M. Schultz. 1990. Relationship between secreted urokinase plasminogen activator activity and metastatic potential in murine B16 cells transfected with human urokinase sense and antisense genes. Cancer Res. 50:76237633.

43. Araki, S.-I., Y. Kawahara, K. Ken-ichi, M. Sunako, T. Tsuda, H. Fukuzaki, and T. Yoshimi. 1990. Stimulation of platelet-derived growth factor-induced DNA synthesis by angiotensin II in rabbit vascular smooth muscle cells. Biochem. Biophys. Res. Commun. 168:350-357.

44. Baudouin-Legros, M., J.-L. Paquet, G. Brunelle, and P. Meyer. 1989. Role of nuclear proto-oncogenes in the proliferation of aortic smooth muscle cells in spontaneously hypertensive rats. J. Hypertens. 7:S114-S115.

45. Kawahara, Y., M. Sunako, T. Terutaka, H. Fuzaki, Y. Fukomoto, and Y. Takai. 1988. Angiotensin II induces expression of the $\mathrm{c}$-fos gene through protein kinase $\mathrm{c}$ activation and calcium ion mobilization in cultured vascular smooth muscle cells. Biochem. Biophys. Res. Comm. 150:52-59.

46. Moalic, J. M., C. Bauters, D. Himbert, J. Bercovici, C. Mouas, P. Guicheney, M. Baudoin-Legros, L. Rappaport, R. Emanoil-Ravier, V. Mezger, et al. 1989. Phenylephrine, vasopressin and angiotensin II act as determinants of protooncogene and heat-shock protein gene expression in adult rat heart and aorta. $J$. Hypertens. 7:195-201

47. Naftilan, A. J., R. E. Pratt, and V. J. Dzau. 1989. Induction of platelet-derived growth factor A-chain and c-myc gene expressions by angiotensin II in cultured rat vascular smooth muscle cells. J. Clin. Invest. 83:1419-1424.

48. Naftilan, A. J., R. E. Pratt, C. S. Eldridge, H. L. Lin, and V. J. Dzau. 1989. Angiotensin II induces c-fos expression in smooth muscle via transcriptional control. Hypertension. 13:706-711.

49. Taubman, M. B., B. C. Berk, S. I. Izumo, T. Terutaka, R. W. Alexander, and B. Nadal-Ginard. 1989. Angiotensin II induces $\mathrm{c}-$ fos mRNA in aortic smooth muscle. J. Biol. Chem. 264:526-530.

50. Sassone-Corsi, P., J. Sisson, and I. Verma. 1988. Transcriptional autoregulation of the proto-oncogene fos. Nature (Lond.). 334:314-319.

51. Takimoto, M., J. P. Quinn, A. R. Farina, L. M. Staudt, and D. Levens. 1989. fos/jun and ocatmer-binding protein interact with a common site in a negative element of the human c-myc gene. J. Biol. Chem. 264:8992-8999. 